\title{
Fairy tale as a method of diagnosing destructive life attitudes in Agrarian University students
}

\author{
Svetlana Nikolaevna Semenkova ${ }^{1 *}$, Olga Nikolaevna Goncharenko ${ }^{1}$, and Aleftina \\ Aleksandrovna Ushakova ${ }^{1}$ \\ ${ }^{1}$ State Agrarian University of the Northern Trans-Urals, Department of Philosophy and Social \\ Sciences and Humanities, Tyumen, Russia
}

\begin{abstract}
The goal of the conducted study is to reveal the possible destructive life attitudes among the student youth of an agrarian university using a projective method. The scientific novelty of the study is predetermined by the communicative-cognitive and psychosomatic approaches and interdisciplinary methods, the primary of them being a projective method: the study identifies the specific characteristics of fairy tales as a method of diagnosing destructive life attitudes in agrarian university students. The study shows that the choice of a fairy tale and the character a young person associates themselves with serves as a projection of personality characteristics and fundamental life attitudes. As a result, it is demonstrated that a fairy tale affects the current state of rural youth who have come to the city to study and expresses their commitment to the rural lifestyle accompanied, however, by a desire for change that under certain conditions can lead to destructive behavior through the activation of inner resources and increased emotional tension.
\end{abstract}

Keywords: fairy tale, projective method, students, socialization, destructive behavior, life attitudes.

\section{Introduction}

Often in their life people repeatedly experience a certain scenario. Such behavior is typically not subjected to criticism by the person since it is based on attitudes and certain inferences made by them as a child.

Everything would be fine if such actions and repeating scenarios brought satisfaction and constructive changes in a person's life. However, such rigid attitudes can inhibit personality development to the point of its degradation. In any case, personality development implies qualitative constructive changes while in repeating scenarios a person is unable to practice new ways of interacting with the outside world. The point is that a person only sees the result of their actions and not the action itself. It is difficult for a person to accept the action rather than the resulting situation as the cause of the problem. It requires gaining awareness of the behavioral scenarios and reactions to certain situations ingrained since childhood and accepted as dogmatic. As a result, a person repeats the same scenario they are not satisfied by over and over while being unable to stop repeating it on their own. Such dissatisfaction

\footnotetext{
*Corresponding author: semenkova.svet@yandex.ru
} 
with the current state can aggravate and provoke many personal problems such as increased anxiety, depression, neuroses, various psychosomatic diseases, and, ultimately, not the best effect on interpersonal relationships and society as a whole.

Among the variety of means allowing us to reveal the perceptions, convictions, attitudes, and behavioral scenarios developed by a person, we can highlight reading and analyzing fairy tales and watching cartoons as these are the examples of the earliest examples of possible life situations and strategies of behavior. A child observing these scenes either draws conclusions regarding their own behavior or views the behavior of the characters as algorithms for their own action in the future. Meanwhile, it is necessary to account for the fact that some characters will become heroes for the child while others will serve as anti-heroes. It is yet unclear whether a child's further behavior strategies are affected by the behavior of a character itself or the character becomes a favorite because they reflect the values and convictions a child already has. Considering that we start watching and listening to fairy tales long before personality development is complete, it can be assumed that fairy tales do influence personality development. After all, it is not in vain that folk wisdom, especially in our country, has taken the form of folk pedagogy and has been passed from the older generation to the younger in the form of fairy tales, myths, and legends shaping a child's worldview. In this case, parents and grandparents have a great influence on the perception of fairy tales and the characters in them. They are the very people who initially offer certain particular fairy tales and cartoons to a child guided by their own preferences and evaluations of the characters' actions. Thus, we can trace the influence of the microsociety and society as a whole on the formation of convictions, values, and norms, among other things, using fairy tales. The texts of fairy tales have quite a strong emotional conscious and unconscious impact on the psyche of adults, and even more so on the psyche of children. A child begins to give preference to a certain fairy tale. If the preferences of adults and children coincide, it is possible to assume a possible repetition of destructive scenarios from the parents' life in the life of the child once they grow up.

The undoubted effect of fairy tales on personality development became a reason for the emergence of a new direction in psychology - fairytale therapy. The first mentions of fairytale therapy date back to the 18th century. People used fairy tales to pass on moral values and attitudes and rules of conduct through generations. Before psychotherapy acquired an official status of a scientific method, fairy tales served as a certain instrument of education and upbringing, a method of folk pedagogy.

At present, fairytale therapy or "treatment with fairy tales" is actively used in applied psychology. Currently well-known psychologist T.D. Zinkevich-Evstigneeva defines fairytale therapy as a set of ways of "the transmission of knowledge about a person's spiritual path and social fulfillment" [1]. A major contribution to the development of this method was made by the works of both Russian (D.B. Elkonin [2], L.S. Vygotsky [3]) and foreign authors (B. Bettelheim [4], C.G. Jung [5], M.-L. von Franz [6], E. Fromm [7], E. Berne [8], N. Peseschkian [9]). Also worth noting are the works of A.N. Gnezdilov [10], I.V. Vachkov [11], N.A. Sakovich [12], and A.A. Osipova [13].

Fairytale therapy is widely used in pedagogical and defectological work with children and is deployed by psychologists in diagnostics and therapy with adults. This method is one of the mildest diagnostic and correctional methods as it belongs to the projective methods of work with clients. Projective methods (from the Latin "projestio" - throwing forward) present a special technique for the experimental study of personality characteristics that are the least accessible through direct observation and surveys. As if on a screen, these methods show the most substantial aspects of personality in their interrelation and holistic functioning [14]. 


\section{Subjects and methods}

The study is conducted using the communicative-cognitive and psychosomatic approaches. The goal of the study is to identify the possible destructive life attitudes of the student youth of an agrarian university using projective methods. About 50 first-year students of the State Agrarian University of the Northern Trans-Urals took part in the study. The choice of the sample is determined by the fact that the majority of the university students come from rural areas. "Close relationships between people, the minimal presence of urbanization processes in the countryside, limited access to certain resources of social and cultural infrastructure, the formation of a particular life strategy (if not us, then who), the emphasis on the development of the sense of justice, conscience, and honor" [15: 32] can cause these students certain difficulties in adaptation to the rapidly changing urban conditions, especially at the beginning of learning. The methods deployed in the process of the study include a questionnaire and interview, comparison and generalization of the content of concepts and categories, qualitative and quantitative analysis of the obtained data obtained, and statistical data processing methods. The main of the utilized methods is a projective one as it allows studying "the unconscious or not quite realized forms of motivation thus being almost the only psychological method of accessing the most intimate area of mentality. ...A projective method allows to indirectly, by modeling some life situations and relations, explore the personality formations functioning directly or in the form of various personal attitudes" [14].

\section{Results}

Analysis of a fairy tale in general and the favorite character in particular can serve as a productive means of diagnosing destructive scenarios and attitudes, as well as the false limiting and distorting convictions and leading the individual to become aware of them. This diagnostic method allows not only analyzing a favorite fairy tale character and tracing the analogy to some scenarios in life but also to realizing that the behavior of a favorite character from childhood manifests itself in a tendency to act in a certain way in adult life as well. Changing one's destructive scenarios and strategies to constructive ones is impossible as long as they remain unconscious. When working with a client, it is often enough for a psychologist to know which fairy tale they read or watched most often and which of its characters is their favorite to grasp the direction of future work.

At times, a person can analyze the fairy tale themselves, however, this work is best to be conducted with a psychologist to avoid resorting to psychological defense mechanisms and remain sufficiently honest and objective. The role of a psychologist in this kind of work is not only to listen and analyze the client's story about the fairy tale and its characters but also to observe the client's reactions that can be highly indicative.

The ranked list of the respondents' answers to the question "Which fairy tale did you like the most as a child?" is as follows:

1. "Morozko" - a Russian folk tale (25\%),

2. "Kolobok" - a Russian folk tale (24\%)

3. "The Scarlet Flower" - S.T. Aksakov (21\%)

4. "The Tale of Tsar Saltan, of His Son the Renowned and Mighty Bogatyr Prince Gvidon Saltanovich, and of the Beautiful Princess-Swan" (a shortened version of the title - "The Tale of Tsar Saltan") - a tale in verse, A.S. Pushkin (19\%).

The remaining $11 \%$ of the respondents named the fairy tales that are less often talked about but remain relevant: "Lisa-lapotnitsa" ["The Ignorant Fox"], "Matiusha Pepelnoi", "Maria Morevna", "The Frog Princess", "Teremok", "Finest, the brave Falcon", "The Little Humpbacked Horse". In one way or another, the mentioned fairy tales communicate the idea that if one powers through the unpleasant ("The Scarlet Flower") and sacrifices themselves 
first ("Morozko", "The Tale of Tsar Saltan", "The Frog Princess"), they will be rewarded. Thus, to be happy, one has to first be a victim, struggle, and wait since obtaining the desired easy way is wrong. In conversations, the students arrived at the understanding that patience (even if something is unpleasant) not always leads to happiness and often contradicts a person's values. Fairy tales with just and good heroes who always help the weak, give them presents, and punish the bad ones ("Morozko", "Finest, the brave Falcon", "The Little Humpbacked Horse") are typically selected by the students who associate themselves with such characters as they fulfill similar functions in certain social circles.

An important component of interpretation of a fairy tale is determining the character a student associates themselves or identifies with. Personality characteristics and attitudes are primarily projected onto this character and through them. The students selected for further work with a psychologist are those who picked the most popular fairy tales - Russian folk tales "Morozko" (25\%) and "Kolobok" (24\%).

To identify the projection character, the students who selected the "Morozko" and "Kolobok" fairy tales were asked the following questions: "Which of the characters is similar to you?", "Which of the characters do you empathize with more?", "What traits about this character appeal to you?", and "What are the similarities between you and this character?" [16: 22]. Having summarized the answers, we can draw the following conclusions:

Firstly, when identifying the character similar to them (Nastenka from the "Morozko" fairy tale or Kolobok from the "Kolobok" fairy tale), the respondents in a new stage of their life assess the main character positively and sympathize and empathize with them. The behavior of the hero of the fairy tale is approved and not criticized even if the character does not reach the goal, dies, or is left with nothing. Thus, the life attitude of the respondents manifests in the attitude "I am OK".

Secondly, the character traits of the chosen characters, Nastenka from the "Morozko" fairy tale (meekness, affability, efficiency, persistence) or Kolobok from the fairy tale of the same name (agile, resourceful, with a good sense of humor, friendly, and sociable but overly self-confident) indicate that the rural young men and women who chose these tales have absorbed agrarian consciousness from their childhood. According to Russian researcher of Russian villages O.N. Goncharenko, this type of consciousness is characterized by "integrity, syncretism of the sensual and rational, figurative and logical, moral and pragmatic" [17: 70].

Thirdly, the "Kolobok" fairytale thoroughly shows interactions with opponents which provides additional information about the hero's traits: boastfulness, narcissism, arrogance, lack of a sense of danger. The main character shies away from confronting his opponents showing arrogance and losing his life at the end of the tale. These traits, the key one among which we believe to be the "lack of a sense of danger", often lead rural youth who find themselves in urban settings to destructive behavior.

Fourthly, in most fairy tales, the main character hopes for a miracle, a talisman, or good luck. Due to the nature of the main characters of the fairy tales most popular among the respondents, social activity does not always manifest as a tumultuous activity but always leads to a certain result. The primary analysis of some fairy tales gives an impression that not all of them carry a constructive message in the actions of the " positive" character. For instance, at first glance, the "Kolobok" fairy tale can cause a child to develop the fear of disobeying or the inability to take on responsibility for their own life and a lack of attention to one's needs. However, there is nothing bad about Kolobok's journey. Although he ended up being eaten by the fox, he would have been eaten in any case and this way, he at least managed to live a rich and interesting life. When reading this tale, it is necessary to draw a correct conclusion that Kolobok was eaten not because of running away from home but due to the presence of a clear rigidity in his behavior. The character used the same trick that was quite effective before the encounter with the fox but failed to consider the change in the conditions thus underestimating the fox. As a result of a correct interpretation of the fairy 
tale, a child has to develop the notion that one cannot stand still but has to constantly learn, adapt to the changing conditions, be more flexible, and continually improve themselves.

\section{Conclusion}

The results of the study indicate that 17-18-year-old students of an agrarian university demonstrate a certain attitude towards themselves and the world reflected in the fundamental resource life attitude formed in childhood through fairy tales which affects their current state characterized by a commitment to the rural lifestyle but also the desire for change associated with moving to the city. Moreover, their life attitude has background characteristics, i.e. is in a latent state and can reveal itself under certain conditions later leading to destructive behavior due to activation of the inner resources and increased emotional tension.

Thus, the study of the structure and content of the components of destructive life attitudes using fairy tales can serve as the basis for the development of strategies and tactics of both group and individual psychological assistance for the adaptation of first-year students in an agrarian university.

Rural youth noticing similar repeating situations in their life in which their actions do not bring constructive changes can refer to their favorite fairy tale or the behavior of a favorite character from childhood in search of rigid attitudes. The resource attitude can be utilized as a means of changing ineffective behavioral strategies and activating the effective ones. This will allow them to not only reveal the unconscious willingness to act within the mentioned scenarios and find that this way of dealing with such situations is not the most effective but also to revise these interactions seeing new possible ways of communicating with other people.

\section{References}

1. T.D. Zinkevich-Evstigneeva, Put k volshebstvu. Teoriia i praktika Skazkoterapii [The way to magic. Theory and practice of fairytale therapy] (Zlatoust, Saint Petersburg, 1998)

2. D. B. Elkonin, Izbrannye psikhologicheskie trudy [Selected works in psychology.] (Pedagogika, Moscow, 1989)

3. L.S. Vygotsky, V.V. Ivanov, Psihologiia iskusstva [Psychology of art], 3rd ed. (Iskusstvo, Moscow, 1986)

4. B. Bettelheim, Pustaia krepost: Detskii autizm i rozhdenie "Ia". [The Empty Fortress: Infantile Autism and the Birth of the Self.] (Akademicheskii proekt, Saint Petersburg, 2004)

5. C.G. Jung, Psikhologicheskie tipy [Psychological types] (Akademicheskii proekt, Moscow, 2019)

6. M.-L. von Franz, Motiv iskupleniia v volshebnykh skazkakh [Redemption motifs in fairy tales], trans. by V. Zelenskii (Dobrosvet, Gorodets, Moscow, 2016)

7. E. Fromm, Chelovek dlia samogo sebia [Man for Himself], trans. from English by E. Spirova (AST, Moscow, 2008)

8. E. Berne, Igry, v kotorye igraiut liudi. Psikhologiia chelovecheskikh vzaimootnoshenii. Liudi, kotorye igraiut v igry. Psikhologiia chelovecheskoi sudby. [Games People Play: The Psychology of Human Relationships. What Do You Say After You Say Hello?: The Psychology of Human Destiny.], trans. from English by L.G. Ionin ("Universitetskaia kniga" AST, Saint Petersburg, Moscow, 1996) 
9. N. Peseschkian, Psikhosomatika i pozitivnaia psikhoterapiia: Per. s nem. [Psychosomatics and Positive Psychotherapy: trans. from German] (Meditsina, Moscow, 1996)

10. A.V. Gnezdilov, Avtorskaia skazkaterapiia [Author's fairytale therapy]. Accessed on: June 30, 2021. [Online]. Available:

https://zlatoiruna.ucoz.ru/samoosvita/gnezdilov_avtorskaja_skazkoterapija.pdf

11. I.V. Vachkov, Vvedenie v skazkoterapiiu, ili Izbushka, izbushka, povernis ko mne peredom... [Introduction to fairytale therapy, or Hut, Hut, turn your face to me...] (Genezis, Moscow, 2011)

12. N. A. Sakovich (ed.), Praktika skazkoterapii [Fairytale therapy practice] (Rech, Saint Petersburg, 2004)

13. A.A. Osipova, Obshchaia psikhokorrektsiia. Uchebnoe posobie. [General psychocorrection. Textbook.] (Sfera, Moscow, 2002)

14. E.T. Sokolova, Proektivnye metody [Projective methods]. Accessed on: June 30, 2021. [Online]. Available: mode: https://prepod.nspu.ru/mod/page/view.php?id=24049

15. S.N. Semenkova, Uspekhi Sovremennoi Nauki i Obrazovaniia [Achievements of Modern Science and Education], 2(2), 31-33 (2017)

16. E.K. Ageenkova, P.M. Larionov, Dialog. Psikhologicheskii i SotsialnoPedagogicheskii Zhurnal [Dialogue. Psychological and Social-Pedagogical Journal], 3, 18-31 (2018)

17. O.N. Goncharenko, Agrarian Bulletin of the Urals, 10(64), 69-71 (2009) 